\title{
Upodmiotowienie ucznia w kontekście ewangelickiej edukacji religijnej
}

Streszczenie: Problematyka artykułu dotyczy sfery upodmiotowienia ucznia w ewangelickiej edukacji religijnej w szkołach ponadpodstawowych na terenie Śląska Cieszyńskiego. Podejmuję tematykę edukacji podmiotowej, która umożliwia pedagogom religii i uczniom wspólne poszukiwanie wartości, sensu życia i dochodzenie do prawdy. Podmiotowo kreowana przestrzeń edukacyjna winna wspierać dochodzenie jednostki do pełnej autonomii i autentyczności, do pełnej tożsamości. W przestrzeni wolności dokonuje się również odkrywanie potencjonalności jednostki ludzkiej, która podejmuje twórczą aktywność na drodze do pełnej i świadomej samorealizacji w świecie. Osoba - podmiot zmierza ku pełnej dojrzałości, przejmując odpowiedzialność za siebie i swoje wybory.

Słowa kluczowe: upodmiotowienie ucznia, Śląsk Cieszyński, ewangelicka edukacja religijna, edukacja międzykulturowa

\section{Wprowadzenie}

„Odzyskanie wolności, demokratyzacja struktur państwa, pluralizacja poglądów na świat oraz wysiłek na rzecz upodmiotowienia wychowania i człowieka jako osoby" (Różańska, 2002, s. 14) stawia także przede wszystkim pedagogom religii pytanie: Jak dalece uczeń, jako młody człowiek, w swojej indywidualności, staje się i jest podmiotem edukacji religijnej?

Ewangelicka edukacja religijna jako zjawisko pedagogiczne, które obecnie zachodzi w przestrzeni placówek oświatowych w szkolnictwie podstawowym i ponadpodstawowym, podkreśla zasadność kształtowania umiejętności refleksyjnej, afirmacyjnej i krytycznej lektury i interpretacji Biblii, jak również stawia sobie za cel kształtowanie umiejętności refleksyjnego, afirmacyjnego i krytycznego podejścia do postaw, zachowań i przekazów religijnych o charakterze historycznym i współczesnym. Nabywanie w trakcie edukacji umiejętności analizowania kwestii egzystencjalnych, etycznych i społecznych, a następnie dokonywania wyborów z perspektywy sensów i wartości oraz kształtowanie 
umiejętności artykułowania, argumentowania i obrony własnych przekonań światopoglądowych (Milerski, 2008) wymaga sformułowania przez jednostkę ludzką świadomych założeń dotyczących samego siebie, a zarazem stanowiących osobisty punkt odniesienia, który ukonstytuowany jest w obszarze bycia osobą o tożsamości odróżniającej daną jednostkę od innych jednostek (Sowa, 2005). Posiadanie tożsamości odróżniającej jednostkę od innych, w ramach której człowiek wierzy, że własna aktywność w znacznym stopniu zależy od niego samego, wyzwala poczucie specyficznej wyjątkowości danej jednostki ludzkiej, to poczucie bycia kimś, to stanie się podmiotem (Lewowicki, 1993).

Młody człowiek, w miarę rozwoju osobistego Ja na drodze samopoznania, angażuje wszystkie poznawcze i emocjonalne zasoby swojej osobowości celem ukształtowania spójnego poczucia, kim jest (Brich i Malim, 1997).

Niewątpliwie przed pedagogiem edukacji religijnej, będącym osobą towarzyszącą dzieciom i młodzieży, często przez wiele lat, stoi zadanie sfokusowania swoich działań pedagogicznych na „duchowych i osobowościowych potrzebach człowieka” (Różańska, 2015, s. 477).

W ostatnim półwieczu różne człony systemów edukacyjnych podlegały niespotykanym dotąd przemianom. Na kształtowanie się nowych refleksji dotyczących innego, bardziej partnerskiego uczestnictwa w poczynaniach edukacyjnych wpłynęło wołanie pedagogów o pełną autonomię i podmiotowość nauczyciela, ale przede wszystkim o podmiotowe traktowanie uczniów. Dlatego też „stałe rozszerzanie i pogłębianie edukacyjnego partnerstwa, podbudowywanego autentyczną obustronną podmiotowością, może stać się prawidłową drogą dla rozwiązań współczesnych dylematów edukacyjnych" (Niemiec, 2009, s. 10). Uczeń i nauczyciel stają się kreatorami i głównymi realizatorami celów, funkcji i zadań edukacyjnych. Udzielone zostaje więc prawo do głoszenia własnych poglądów, wnoszenia i przyjmowania uwag i propozycji oraz projekcji dotyczących treści kształcenia, zadań wynikających z funkcji opiekuńczych i oddziaływań wychowawczych. Ponadto jest to gotowość do dialogu i wzajemnych uzgodnień, ale zarazem nauka poszanowania zróżnicowań stanowisk (Niemiec, 2009, s. 10).

Na gruncie pedagogiki problem podmiotowości był rozpatrywany w perspektywie aksjologicznej i teologicznej, jak również występuje w ontologii procesu wychowania (Górniewicz, 2001). I jak wskazuje Józef Górniewicz, „badania pedagogiczne nad podmiotowością dotykają najgłębszych i fundamentalnych zagadnień ludzkiej egzystencji. Wychowanie nie może się dokonywać poza podmiotowością. Wychowanie jest w swej istocie tworzeniem owej podmiotowości" (Górniewicz, 2001, s. 41). 
Na Śląsku Cieszyńskim lekcje religii ewangelickiej prowadzone są w placówkach oświatowych, natomiast w diasporach ewangelickich, na terenie całej Polski, zajęcia dydaktyczne mają miejsce w salach parafialnych. Edukacja religijna obejmuje dzieci od piątego do piętnastego roku życia i są to zajęcia obligatoryjne. Natomiast młodzież do osiemnastego bądź dziewiętnastego roku życia bierze udział w spotkaniach młodzieżowych lub lekcjach, które w szkołach ponadpodstawowych są zajęciami fakultatywnymi.

Podmiotem moich badań są uczniowie szkół ponadpodstawowych, przedmiotem natomiast charakter procesu dydaktyczno-wychowawczego edukacji religijnej, którego przebieg niewątpliwie może kształtować podmiotowość młodego człowieka.

\section{Czy edukacja religijna jest sferą upodmiotowienia młodego człowieka?}

W dyskursie pedagogicznym często rozważa się problem upodmiotowienia młodego człowieka i stawia pytanie: Czy edukacja wspiera czy też hamuje proces upodmiotowienia? Zatem moje pytanie badawcze, na które poszukuję odpowiedzi, brzmi: Czy edukacja religijna jest sferą upodmiotowienia młodego człowieka?

Celem badań własnych, których wyniki zostaną przedłożone w niniejszym artykule, jest pozyskanie wiedzy dotyczącej upodmiotowienia procesu dydaktycznego, a zatem wspierania rozwoju podmiotowości wychowanka w ewangelickiej edukacji religijnej w szkołach ponadpodstawowych. Poszukując odpowiedzi na nurtujące mnie pytania, opracowałam kwestionariusz wywiadu częściowo skategoryzowanego, zawierającego sześć pytań otwartych, skonstruowanych na podstawie definicji podmiotowości.

Dla pedagogów podmiotowość oznacza, że człowiek jest kimś, kto ma określoną tożsamość, a jego własna działalność i rozwój zależy w znacznym stopniu od niego samego. Ponadto podmiotowość jest zdolnością uświadamiania sobie przez człowieka faktu podlegania przemianom oraz możności autonomicznego wpływu na owe przemiany. Jednak aby jednostka mogła być podmiotem swojej działalności, musi być świadoma swojego osobistego systemu wartości. Natomiast „podmiotowe traktowanie człowieka to takie jego postrzeganie, które daje mu prawo do własnej niezależności” (Klim-Klimaszewska, 2009, s. 236).

Podmiotowe funkcjonowanie ucznia to jego prawo do kreatywnego współudziału i autentycznego współtworzenia procesu edukacyjnego implikującego 
jego poczucie odpowiedzialności za własne postępowanie (Klim-Klimaszewska, 2009). Z powyższym zagadnieniem podmiotowości oraz sferą upodmiotowienia lekcji religii ewangelickiej skonfrontowałam młodzież zamieszkującą Śląsk Cieszyński, a uczęszczającą do klas pierwszych, drugich i trzecich II Liceum Ogólnokształcącego im. Mikołaja Kopernika w Cieszynie. W wywiadzie licealiści (jedenaście dziewcząt i czterech chłopców) udzielili obszernych odpowiedzi na pytania dotyczące oddziaływania edukacji religijnej na kształtowanie tożsamości chrześcijańskiej, zaangażowania uczniów we współtworzenie procesu dydaktycznego lekcji religii oraz treści uczących dojrzałości i przyjmowania odpowiedzialności za swoje decyzje i czyny podejmowane w życiu. Wszystkie wypowiedzi badanej młodzieży w niniejszym artykule zostały przytoczone $\mathrm{w}$ oryginalnym brzmieniu.

\section{Edukacja a tożsamość podmiotu}

Czym jest zatem edukacja podmiotowa? Zdaniem Andrzeja Olubińskiego (2001) edukacja podmiotowa jest wychowaniem przez doświadczenie, porozumiewaniem się, które umożliwia wspólne poszukiwanie wartości, sensu życia i dochodzenie do prawdy. Podmiotowo kreowana przestrzeń edukacyjna wspiera dochodzenie jednostki do pełnej autonomii i autentyczności, do pełnej tożsamości. Jacek Poprzeczko, postulujący podmiotowość człowieka jako kategorię centralną, sądzi, że „dociekanie własnej tożsamości jest niezbywalnym atrybutem człowieczeństwa. Zaczęło się ono od momentu uzyskania świadomości siebie i nigdy się nie skończy" (Poprzeczko, 1988, s. 30).

Problematyka podmiotowości, jak pisze Irena Wojnar (2000), nabiera w naszym kraju istotnego znaczenia. Autorka książki pod tytułem: „Humanistyczne intencje edukacji” poszukuje odpowiedzi na pytanie: Czy i na ile edukacja może stanowić dla konkretnego człowieka źródło osobistej samowiedzy i samookreślenia? Człowiek musi bowiem odpowiedzieć sobie na pytanie: Jakie są realne podstawy jego osobistej tożsamości? Podejmując ten tok myślenia, chciałabym rozważyć zagadnienie upodmiotowienia ewangelickiej edukacji religijnej w kontekście omawianych treści, a także tworzenia przestrzeni, umożliwiającej podmiotom wychowania spotkanie się z samym sobą oraz uświadomienie sobie wymiarów własnego istnienia i własnej potencjonalności.

„Problem tożsamości jest zasadniczo zagadnieniem metafizycznym, bowiem pierwsze kontury nadał mu Parmenides, rozważając byt jako taki" (Morszczyński, 2008, s. 31), a zarazem zdefiniował podstawową formułę toż- 
samość bytu: „jest to, co jest”. Współcześnie antyczna teza filozofa z Elei służy do wyrażania kwestii tożsamości osoby, gdyż poczucie braku punktów odniesienia dla konstytuowania się jednostkowej tożsamości Ja, jak pisze Barbara Skarga (1997), budzi w człowieku lęk przed jej utratą. Piotr Sztompka (2002) podkreśla natomiast, że niepowtarzalną tożsamość indywidualną jednostki tworzą cechy przysługujące wyłącznie jej, i nie stanowią ich jedynie cechy genetyczne, ale także wyznawane przekonania i wartości. W przestrzeni moralnej winna mieć zatem miejsce autodefinicja jednostki, dotycząca jej własnego miejsca i granic przestrzeni moralnej. Zagadnienie tożsamości indywidualnej, jak pisze Morszczyński (2008), nie powinno być rozważane jedynie przez filozofię, również pedagog, będący w częstym kontakcie interpersonalnym ze swoimi wychowankami, nie może pominąć tego rodzaju tożsamości.

Zainteresowała mnie refleksja młodzieży nad poznanymi treściami tekstu Pisma Świętego, stanowiącymi źródło i podstawę chrześcijańskiej tożsamości. Na zadane licealistom pytania: Czy i jakie treści w edukacji religijnej kształtują Twoją tożsamość chrześcijańską? Kim jest chrześcijanin w kontekście Biblii?, młodzi ludzie nawiązują do treści zarówno Starego, jak i Nowego Testamentu. Identyfikacja swojej tożsamości mającej początek w Ewangeliach i w Listach Apostoła Pawła pojawia się zdecydowanie częściej aniżeli odniesienia do treści zawartych w Księdze Rodzaju. Jednak, jak deklarują respondenci, wersety zapisane w Pierwszej Księdze Mojżeszowej „uzmysławiają nam, że jesteśmy stworzeni na obraz i podobieństwo Boga, ponadto posiadamy cechy, które czynią nas podobnymi do Niego".

Wśród wartości, które przejawiają się w człowieku młodzież, podaje: twórczość, kreatywność, dobroć, wierność, okazywanie miłosierdzia, miłości i przebaczenia. Rzadziej wymienia łaskę, sprawiedliwość, mądrość, łagodność czy świętość. W kontekście nauk Jezusa uczniowie identyfikują się z pojęciem Dziecka Bożego podobnego do Ojca Stwórcy. Dziecka, „które uwierzyło w Jezusa i przyjęło Go, zostało napełnione Duchem Świętym, który daje mu gwarancję, że nigdy nie zostanie odłączone od Boga”. „Jestem Bożym dzieckiem, które zostało stworzone, aby pomagać”. „Obcowanie ze Słowem Bożym daje mi cenną świadomość przynależności do Boga”. „Moją chrześcijańską tożsamość kształtuje przede wszystkim Słowo Boże, które próbuję dogłębniej zrozumieć". „Poszczególne fragmenty i wersety, choć wcześniej już znane, często nabierają w moim postrzeganiu nowego sensu”. „Skupianie się nad Pismem buduje nas duchowo i coraz mocniej utwierdza mnie w wierze”. „Lekcje religii zdecydowanie mają wpływ na kształtowanie się mojej tożsamości chrześcijańskiej. Dzięki temu, że są one w szkole, mam możliwość kontaktu z Bogiem". 


\section{Wolność i twórczość podmiotowa}

Józef Górniewicz (2001) podaje, iż podmiotowość określa się najczęściej jako wewnętrzne źródło wszelkiej przyczynowości, której warunkiem jest istnienie wolności. Irena Wojnar (2000) podkreśla, iż tylko podmiot niezdeterminowany w swoich działaniach może wydobywać inspirację ze swojego wnętrza. Kreatywność jest potrzebą i możliwością każdej ludzkiej jednostki. Twórcza aktywność stanowi drogę do pełnej i świadomej samorealizacji konkretnego człowieka w świecie. A jak wskazuje Kazimierz Gryżenia (2010), filozofia klasyczna traktuje człowieka jako dynamiczny byt osobowy, o nieskończonej wręcz potencjonalności, który znajduje się na drodze ku pełni człowieczeństwa. Ustawiczny rozwój człowieka polega na budowaniu samego siebie w celu dochodzenia do pełnej dojrzałości. Owo doskonalenie się urzeczywistnia się w działaniu o charakterze osobowym, to znaczy w działaniu naznaczonym poznaniem, miłością i wolnością. Zdaniem Woronieckiego „pełny rozwój człowieka, czyli harmonijne zaktualizowanie potencjonalności zawartych w człowieku jest możliwe tylko przy uwzględnieniu ostatecznego celu życia, jakim jest powrót do Boga,z którego rąk wyszedł i do którego u kresu życia ma wrócić" (Woroniecki, 1961, s. 87).

Niewątpliwie aktualizacja potencjonalności „danych” każdej jednostce ludzkiej jest autonomiczną decyzją poszczególnego człowieka. Osoba ludzka jako podmiot intelektualnych i/lub fizycznych sprawności podejmuje decyzję, które z nich i w jaki sposób będzie rozwijać i urzeczywistniać w życiu. Przy czym zespół genetycznych i wrodzonych uwarunkowań rozwoju człowieka podlega ograniczeniom, potencjonalności moralne natomiast takim ograniczeniom nie podlegają. Doskonałość moralną może osiągnąć każda jednostka, a zatem, jak pisze Kazimierz Gryżenia (2010), każda osoba ma możność zrealizowania pełni swojego człowieczeństwa. Samostanowienie, w którym zakorzeniona jest wolność jako moc rozstrzygania i wybierania, należy do natury osoby ludzkiej. Człowiek, zdaniem Agnieszki Łagody (2010), dokonując wyboru, realizuje swoją wolność, urzeczywistnia się poprzez czyny, a zarazem spełnia w nich siebie.

„W aspekcie teodycealnym człowiek posiada źródło swej wolności w Bogu [...], Bóg - choć ukryty - jest zawsze obecny w samorealizacji ludzkiej" (Bartnik, 1995, s. 285). Wolność osobowa jest jak najgłębiej podmiotowa, a przez nią i w niej osoba dąży do spełnienia się w zakresie swojej potencjonalności. Dlatego też edukacja religijna winna być nacechowana wolnością i twór- 
czością podmiotową. Młodzież, wychodząc naprzeciw swojemu powołaniu i preferencjom, odkrywa swoje talenty i realizuje siebie poprzez rożne formy zaangażowania się i współtworzenia zajęć wraz z pedagogiem religii. Poprosiłam więc, aby uczniowie odnieśli się do następującego zagadnienia: Czy i jak często są współtwórcami zajęć dydaktycznych? oraz podali przykłady swojego zaangażowania w kreowanie lekcji. Respondenci często podkreślali, że czują się współtwórcami niemalże wszystkich zajęć: „Współtwórcą zajęć religii jestem tak naprawdę na każdej lekcji”. „Myślę, że jestem, a przede wszystkim chcę być współtwórcą zajęć”. „Często na lekcji zadaję pytania, które odbiegają od głównej sentencji zajęć”. „Często sugerujemy tematy, które można by poruszyć na lekcji”. „Tak, często dyskutujemy na różne tematy związane z Bogiem”. Młodzież, „dzięki otwartości nauczyciela”, dokonuje wyboru form i metod kreowania zajęć. Wśród najczęściej wymienianych pojawiają się: przygotowywanie prezentacji na wybrane tematy, dyskusja, prezentacja własnych poglądów, opinii dotyczących osobistego postrzegania omawianych tematów, zadawanie nurtujących pytań, wybór wartościowych i interesujących filmów, jak również frapujących tematów, nawiązywanie do współczesnych wydarzeń na arenie międzynarodowej. Uczniowie wymieniają także różnorodność możliwości, które otrzymują w zakresie oprawy muzycznej lekcji, w tym proponowanie i przygotowanie pieśni, piosenek czy kolęd, gra na instrumentach takich jak skrzypce, keyboard czy gitara.

Czesław Stanisław Bartnik (1995) pisze, że samorealizacja dokonuje się poprzez prawdę, dobro i piękno, a dzięki tworzeniu oraz przeżywaniu wartości człowiek staje się osobą. Realizacja prozopoiczna związana jest z całym zwartym systemem wartości, w którym na czoło wysuwa się wolność. Wolność jawi się jako wolność wyboru, działania, tworzenia, estetyczna, kulturowa, moralna, wolność wyrazu osobowego, a wreszcie wolność formowania osoby. Wybór, którego dokonuje człowiek w świecie wartości, decyduje o jego rozwoju osobowym. Stąd też, zdaniem Krystyny Chałas (2006), na drodze do pełni człowieczeństwa wyrasta zadanie kształtowania umiejętności i urzeczywistniania wolnego wyboru wartości.

\section{Dojrzałość i odpowiedzialność podmiotu}

"Wolność jest człowiekowi dana, musi więc być za nią odpowiedzialny" (Chałas, 2006, s. 146). Krystyna Chałas (2006) podkreśla, że właściwościami podmiotu decydującymi o jego dojrzałości do odpowiedzialności są: świadomość, dobrowolność, umiejętność, jak również wskazanie motywów własnego 
działania. Józef Tischner podkreśla, że u podstaw odpowiedzialności znajduje się wolność: „Tylko wtedy można przypisać jakiś czyn podmiotowi działania, gdy podmiot ten jest wolny, gdy działa świadomie i z własnej woli" (Tischner, 1995, s. 48). Górniewicz (2001), nawiązując do myśli Romana Ingardena, twierdzi, że odpowiedzialność musi być zakorzeniona w istocie i strukturze istoty ludzkiej, a jej fundamentem jest ścisła identyczność podmiotu. Najbardziej elementarną podstawą odpowiedzialności podmiotowej, jak zaznacza Ewa Podrez (1999), jest odpowiedzialność przed samym sobą. Człowiek jest odpowiedzialny przed sobą za swoją tożsamość, samowychowanie oraz samodoskonalenie. „Odpowiedzialność wobec siebie za indywidualną treść osobowości, wiąże się bezpośrednio z ponoszeniem odpowiedzialności za swoje wybory związane ze światem »innych «" (Nowicka-Kozioł, 1997, s. 43).

Maria Nowicka-Kozioł podkreśla, że taka odpowiedzialność wiąże się z uznaniem ważności egzystencji drugiego człowieka oraz z istnieniem międzyludzkich więzi. A zatem „człowiek będący podmiotem odpowiedzialności jest źródłem oceny moralnej własnych czynów, wypowiedzi, zachowań oraz uczestnikiem sytuacji i zdarzeń, w których uczestniczą też inne osoby" (Górniewicz, 2001, s. 18). Warto zatem zadać pytanie: Czy i w jaki sposób pedagogia religijna uczy postawy odpowiedzialności za podejmowane decyzje/czyny? Zdaniem młodzieży kształtowanie postawy odpowiedzialności wynika z poznawania lektury Pisma Świętego oraz jego przesłania, które również dzisiaj jest aktualne. Respondenci odwołują się do najwyższych chrześcijańskich wartości, do Boga, Boga Syna, Jego Słowa oraz Dekalogu, które stanowią fundament nie tylko ich wiary chrześcijańskiej, ale również ich chrześcijańskiej odpowiedzialności przed Bogiem, samym sobą oraz drugim człowiekiem, bliźnim.

O kształtowaniu postawy dojrzałej odpowiedzialności młodzież pisze w następujący sposób: „Wiedza przyswojona na lekcjach często przypomina mi się w różnych sytuacjach, zwłaszcza gdy czytam omawiane już wersety, łatwiej mi je zrozumieć. Zaś podejmowane decyzje są konsekwencją mojej wiary. Gdy zrozumiem, że wybór, którego dokonałam nie przybliża mnie do Pana Boga odczuwam rozbicie. Jednak coraz częściej „słyszę” wyznawane przeze mnie chrześcijańskie wartości, które pomagają mi żyć zgodnie z wolą Bożą”. „Kiedy czytamy Biblię, to ona uczy nas jak mamy postępować, odróżniać dobro od zła, jak należy zachować się w danej sytuacji lub jak zachowywać się w stosunku do drugiej osoby. Jezus oddał się za nasze grzechy, dlatego powinniśmy być odpowiedzialni za to, co robimy”. „Dzięki temu, że na każdej lekcji poznajemy Słowo Boże wiem, co jest dobre, a co złe. Zajęcia ukształto- 
wały we mnie pewien kręgosłup moralny, sprawiły, że jestem bardziej wrażliwa na przestrzeganie Dekalogu, a co za tym idzie, na postępowanie wobec drugiego człowieka”. „Nauczanie religijne uczy szacunku do wszystkich ludzi, nie patrząc na ich wiarę, tradycję i pochodzenie, a także inną religię. Uczy także sprawiedliwości i odpowiedzialności, nie tylko w stosunku do innych ludzi, ale także względem moich własnych czynów”. „W pewnym sensie religia przypomina nam i tłumaczy Słowo Boże, żebyśmy nim żyli i się nim kierowali. Abyśmy mieli świadomość, jakie grzechy popełniamy i byśmy mogli się ich wystrzegać. Religia uczy jak żyć z Bogiem”. „Pomaga mi uzmysłowić sobie, jakie decyzje mogą mieć dobry wpływ na moje życie i czy mogą podobać się Panu, a jakie nie. Dzięki temu zdobywam doświadczenie i jestem w stanie podejmować decyzje i odpowiedzialność związaną z nimi”. „Nauczanie religijne uczy mnie odpowiedzialności za podejmowane decyzje i czyny. Dzięki religii nauczyłam się, że czasem ponosimy konsekwencje, i że należy zastanowić się, co w danej sytuacji zrobiłby Pan Jezus”. „Nauczanie religijne może kształtować postawę odpowiedzialności za swoje decyzje/czyny przez poznanie danej kwestii przedstawionej w Biblii. Poznając postaci opisane w Piśmie Świętym zastanawiamy się, w jaki sposób one postępowały w określonych sytuacjach, i kiedy mogą być dla nas autorytetem wiary chrześcijańskiej”. „Nauczanie religijne ma duży wpływ na postrzeganie życia i jego planowanie. Myślę, że religia uczy nas, że nie wszystko możemy sobie zaplanować, i że my sami nie jesteśmy w stanie w pełni kontrolować swojego życia. Ponadto uczy nas, czym powinniśmy się kierować i jakie wartości dla nas chrześcijan powinny być ważne. Słowo Boże możemy poznawać od życiowej, codziennej strony. Uczy, że jestem odpowiedzialna za swoje życie oraz decyzje, i że to ja będę musiała ponosić konsekwencje swoich wyborów".

Młodzież, udzielając odpowiedzi na powyższe zagadnienie, podaje również przykłady decyzji i czynów, w których realizacji pomogły jej lekcje religii: „Lekcje religii naprowadzają nas na dobrą drogę, aby unikać grzechu i abyśmy byli go świadomi. Jednak to od nas zależy czy Słowo Boże przyjmiemy do serca i czy o nim pamiętamy w życiu codziennym. Staramy się być dobrzy i dobroduszni, by nie zasmucać Ducha Świętego i kochać swoich bliźnich. W szkole możemy właśnie pomagać swoim rówieśnikom i pokazywać nasze chrześcijaństwo wybaczając błędy innym”. „Lekcje religii nauczyły mnie współpracy z innymi ludźmi. Na zajęciach nauczyciel zawsze jest otwarty na nasze zdanie, słucha, co mamy do powiedzenia. Dzięki temu ja również nauczyłam się słuchać innych”. „Lekcje upewniły mnie w tym, że powinnam częściej rozmawiać z Bogiem, konsultować z Nim moje decyzje 
i prosić o wskazówki” „Pomogły mi w podjęciu decyzji, aby poświęcić swój wolny czas na wolontariat podczas Tygodnia Ewangelizacyjnego w Dzięgielowie aby tam pomagać dzieciom w wieku przedszkolnym i szkolnym, a także aby mogły dowiedzieć się więcej o Jezusie”. „Pomagając bezinteresownie drugiej osobie byłam zadowolona $\mathrm{z}$ tego, że mogłam pomóc w nauce, a koleżanka otrzymała ocenę celującą”. „Choć nie chcę podawać przykładów, lekcje religii pomogły mi w realizacji wielu trudnych życiowych decyzji”. „Dla mnie szczególnie pomocna okazała się lekcja o miłości i zakochaniu, do które ciągle wracam. Pomogła mi zrozumieć jak je rozróżnić i w jakiej sytuacji się znajduję”. „Lekcje religii umocniły mnie w wierze chrześcijańskiej. Odegrały ważną rolę kształtując niejako moje poglądy. Zajęcia pomogły mi również zrozumieć wiele trudnych tekstów z Pisma Świętego, których treść mnie nurtuje a zrazem problem, który był w nich zawarty".

Powyżej przytoczone wypowiedzi młodzieży moim zdaniem nacechowane są refleksją pozytywną, która zdaje się stanowić odzwierciedlenie zachodzących w ewangelickiej edukacji religijnej procesów upodmiotowienia. Można to tłumaczyć tym, że młodzież, która w swojej wolności dokonała wyboru uczestniczenia w zajęciach fakultatywnych oraz wzięła udział w badaniach, również czuje się podmiotem mającym wpływ na kształtowanie otaczającej jej rzeczywistości. Słowami Ireny Wojnar (2000) chciałabym podsumować wypowiedzi młodzieży: osoba - podmiot jest obdarzona poczuciem własnej tożsamości, a także własnej godności, odznacza się intencjonalnością przeżyć i dążeń, stanowi podmiot swoich własnych wyborów, zmierzając ku coraz pełniejszej doskonałości i samorealizacji.

\section{Konkluzje}

Zarówno religia, jak i edukacja, jak pisze Bogusław Milerski (1998), stanowią zagadnienia o znaczeniu egzystencjalnym, dlatego też autor wyraża pogląd, iż pomiędzy pedagogiką a religią możliwy jest dialog, który winien być prowadzony w imię podmiotowości człowieka. Milerski (1998) podkreśla również, że edukacja religijna to nie tylko wychowanie w perspektywie eklezjalnej, ale także element wychowania całościowego i humanistycznego. Wychowanie jest zatem, zdaniem Kazimierza Gryżeni (2010), konieczną pomocą pedagoga w drodze do pełni człowieczeństwa wychowanka, tak jak konieczność współdziałania w celu możliwie pełnego rozwoju potencjonalności. Nie oznacza jednak utraty tożsamości i samodzielności człowieka, ani nie niweczy jego podmiotowości. Bowiem „wychowanie podmiotowe to takie, które sytuację 
wychowawczą, wyznaczoną zawsze układem ludzi, rzeczy i zadań traktuje jako sytuację dwupodmiotową" (Gurycka, 1989, s. 14).

To właśnie szkole przypisuje się znaczącą rolę w przekazie wartości funkcjonujących w społeczeństwie, a ważnym zadaniem staje się „poszukiwanie sensownych i satysfakcjonujących wzorców życia w perspektywie poszanowania godności, wolności, odpowiedzialności, miłości" (Chałas, 2006, s. 8). Postulat integralnej wizji człowieka i wychowania zawiera „Deklaracja o wychowaniu chrześcijańskim”, w której czytamy: „Prawdziwe zaś wychowanie dąży do kształtowania osoby ludzkiej, mając na względzie jej cel ostateczny i jednocześnie dobro społeczeństw, których członkiem jest człowiek [...]. Wykorzystując postęp nauk psychologicznych, pedagogicznych i dydaktycznych, należy pomagać dzieciom i młodzieży w harmonijnym rozwijaniu wrodzonych zalet fizycznych, moralnych i intelektualnych oraz w stopniowym nabywaniu coraz większego poczucia odpowiedzialności za właściwe kształtowanie życia i dążenie do prawdziwej wolności tak przez nieustanny wysiłek, jak i przez odważne i wytrwałe przezwyciężanie przeszkód” (Milerski, 2011, s. 217).

Kształcenie religijne proponuje zatem określoną hermeneutykę ludzkiej egzystencji, jest przedmiotem, który spełnia podstawowe zadanie edukacji humanistycznej, bowiem ukazuje znaczenie wymiaru egzystencjalnego w kształceniu, „a zarazem umożliwia pozyskanie określonego samozrozumienia, tożsamości i orientacji w świecie" (Milerski, 2011, s. 125).

\section{Bibliografia}

Bartnik, Cz. S. 1995. Personalizm. Lublin: Oficyna Wydawnicza Czas. Brich, A., Malim, T. 1997. Psychologia rozwojowa w zarysie. Od niemowlęctwa do dorostości. Warszawa: Wydawnictwo Naukowe PWN.

Chałas, K. 2006. Wychowanie ku wartościom. Elementy teorii i praktyki. Tom I. Godność, wolność, odpowiedzialność, tolerancja. Lublin - Kielce: Wydawnictwo JEDNOŚĆ.

Górniewicz, J. 2001. Kategorie pedagogiczne. Odpowiedzialność - podmiotowość - samorealizacja - tolerancja - twórczość - wyobraźnia. Olsztyn: Wydawnictwo Uniwersytetu Warmińsko-Mazurskiego.

Gryżenia, K. 2010. Substancjalność i tożsamość u podstaw osobowego rozwoju i wychowania człowieka. W: Michalski, J. i Zakrzewska, A. red. Pedagogika chrześcijańska. Tradycja. Wspótczesność. Nowe Wyzwania. Toruń: Wydawnictwo Adam Marszałek, ss. 367-379. 
Gurycka, A. 1989. Podmiotowość w doświadczeniach wychowawczych dzieci i młodzieży. W: Kofta, M. red. Wychowanek jako podmiot działań. Warszawa: Wydawnictwo Uniwersytetu Warszawskiego, ss. 9-24.

Klim-Klimaszewska, A. 2009. Podmiotowość. W: Jedynak, S. i Kojkoła, J. red. Encyklopedia filozofii wychowania. Bydgoszcz: Oficyna Wydawnicza Branta.

Lewowicki, T. 1993. Podmiotowość w edukacji. W: Pomykało, W. red. Encyklopedia Pedagogiczna. Wyd. I. Warszawa: Fundacja Innowacja, ss. 592-599.

Łagoda, A. 2010. Chrześcijańska koncepcja człowieka jako osoby świadomego i wolnego podmiotu w poglądach Karola Wojtyły. W: Michalski, J. i Zakrzewska, A. red. Pedagogika chrześcijańska. Tradycja. Wspótczesność. Nowe Wyzwania. Torun: Wydawnictwo Adam Marszałek, ss. 241-250.

Milerski, B. 1998. Elementy pedagogiki religijnej. Warszawa: Chrześcijańska Akademia Teologiczna w Warszawie.

Milerski, B. 2008. Podstawa programowa nauczania religii ewangelickiej w szkotach podstawowych, gimnazjalnych i ponadgimnazjalnych. Warszawa: Kościół Ewangelicko-Augsburski w RP, Wydawnictwo WARTO.

Milerski, B. 2011. Hermeneutyka pedagogiczna. Perspektywy pedagogiki religii. Warszawa: Wydawnictwo Naukowe ChAT, ss. 216-232.

Morszczyński, W. 2008. Metafizyczne a kulturowe wyznaczniki tożsamości człowieka. W: Lewowicki, T., Grabowska, B. i Różańska, A. red. Socjalizacja $i$ kształtowanie się tożsamości - problemy i sugestie rozwiazań. Toruń: Wydział Etnologii i Nauk o Edukacji, Wyższa Szkoła Pedagogiczna Związku Nauczycielstwa Polskiego w Warszawie, Wydawnictwo Adam Marszałek, ss. 31-37.

Niemiec, J. 2009. Podmiotowość w intencjach edukacyjnych. W: Niemiec, J. i Popławska, A. red. Podmiotowość we współczesnej edukacji. Oglady intencje - realia. Białystok: Wydawnictwo Niepaństwowej Wyższej Szkoły Pedagogicznej w Białymstoku, PRYMAT, ss. 9-13.

Nowicka-Kozioł, M. 1997. Odpowiedzialność w świetle alternatyw wspótczesnego humanizmu. Wyd. 2. Warszawa: Wydawnictwo Wyższej Szkoły Pedagogiki Specjalnej.

Olubiński, A. 2001. Podmiotowość roli nauczyciela $i$ ucznia w świetle analiz opinii spotecznych. Wyd. II. Toruń: Wydawnictwo Adam Marszałek.

Podrez, E. 1999. Moralne uzasadnienie tolerancji. Studium z etyki personalistycznej. Warszawa: Wydawnictwo Akademii Teologii Katolickiej.

Poprzeczko, J. 1988. Podmiotowość człowieka i społeczeństwa. Warszawa: Państwowe Wydawnictwo Naukowe. 
Różańska, A. 2002. Działalność Edukacyjna Ślaskiego Kościoła Ewangelickiego Augsburskiego Wyznania na Zaolziu. Czeski Cieszyn: Śląski Kościół Ewangelicki Augsburskiego Wyznania.

Różańska, A. 2015. Edukacja religijna młodzieży w warunkach pluralizmu religijnego w wybranych krajach Europy Środkowo-Wschodniej (Grupa Wyszehradzka i Polska, Czechy, Stowacja, Wegry) - studium porównawcze. Toruń: Wydawnictwo Adam Marszałek.

Skarga, B. 1997. Tożsamość i różnica. Eseje metafizyczne. Kraków: Wydawnictwo Znak.

Sowa, J. 2005. Podmiotowość w wychowaniu. W: Pilch, T. red. Encyklopedia Pedagogiczna XXI wieku. T. IV. Warszawa: Wydawnictwo Akademickie „Żak”.

Sztompka, P. 2002. Socjologia. Analiza społeczeństwa. Kraków: Wydawnictwo Znak.

Tischner, J. 1995. Gra wokół odpowiedzialności. Znak. 10, s. 47-55.

Wojnar, I. 2000. Humanistyczne intencje edukacji. Warszawa: Wydawnictwo Akademickie „Żak”.

Woroniecki, J. 1961. Wychowanie człowieka. Pisma wybrane. Kraków: Wydawnictwo Znak.

\section{The empowerment of a learner in the context of Evangelical religious education}

Abstract: The issue of the article concerns the sphere of empowering the student in Evangelical religious education in secondary schools in Cieszyn Silesia. I undertake the issue of subject education, which enables religion educators and students to search for values, the meaning of life and reaching the truth. The subjectively created educational space should support the individual's investigation into full autonomy and authenticity, to full identity. In the space of freedom, one also discovers the potential of the human individual who undertakes creative activity on the path to full and conscious self-fulfillment in the world. The person - the subject is moving to full maturity, taking responsibility for themselves and their choices.

Keywords: empowering of the student, Cieszyn Silesia, Evangelical religious education, intercultural education

Translated by Jerzy Marcol 